\title{
Development and Validation of School Heads' Competencies and Appropriateness of Roles and Functions Through Exploratory Factor Analysis
}

\author{
Lorebina C. Carrasco, Renato L. Base* \\ alore_carrs@yahoo.com,renato.base@ustp.edu.ph \\ Department of Education Division of Cagayan de Oro,Fr. William Masterson Road, Upper Balulang, Cagayan de Oro City 9000, Philippines \\ University of Science and Technology of Southern Philippines, C.M. Recto Highway, Cagayan de Oro City 9000, Philippines
}

\begin{abstract}
The primary aim of the study was to examine the alignment of school-heads trainings and seminars with that of their professional development needs as school administrators. Such findings would then be utilized in order to come up with pertinent policy recommendations, which could be the basis in coming up with strategic plan, for more effective impact of trainings and seminars that the Department of Education would be extending to the school-heads in the City Schools Division of Cagayan de Oro. The scope of this study was limited to seventy elementary level school-heads in the City Schools Division of Cagayan de Oro. The research was descriptive and correlational in nature. Structured questionnaires were used for gathering information about school-heads professional development needs. This was correlated with that of their perceived agreement as to the relevance of trainings they attended relative to their role and functions as school administrators. The findings have shown that trainings and seminars conducted were aligned with the professional development needs of the school heads as they perform their roles and functions. However, not all topics in the trainings conducted were able to address the desired competencies. It was also found out that although there is alignment of the trainings and seminars, there is still a need to consult and summarize their professional development needs in identifying topics for trainings conducted at different levels. The proposed training design for school heads shall be checked, monitored and evaluated by the Performance Management Team (PMT) as to alignment of topics to the professional development needs.
\end{abstract}

Published by IJRP.ORG. Selection and/or peer-review under responsibility of International Journal of Research Publications (IJRP.ORG)

Keywords: Type your keywords here, separated by semicolons ;

\section{Introduction}

In the $21^{\text {st }}$ century school environment, the competence of school-heads is being challenged by many factors as educational context now becomes more complex and diverse, and these are potentially overwhelming for school's administrators (Barnett and McCormic, 2012: 653).To address such challenges, the Department of Education issued a department order in the form of National Competency-Based Standards for School-heads Training and Development Needs Assessment, as a mechanism to systematically determine the training and development needs of school-heads(DepEd, 2010). In this department order, it listed the required competencies useful for decision-making, actions and performance given the complexity and diversity that impinge on their role as school's administrators. These competencies became the basis in the preparation of trainings and seminars to ensure school-heads efficiency, effectiveness, and excellence (DepEd 
Order No. 32, s. 2010, par.2 and 3). Supposedly, these training activities were intended to address the challenges facing the school's administrators in the $21^{\text {st }}$ century school environment. These include but not limited to bureaucratic leadership contexts; personal conflict; lack of support and proper instruction from high education levels; cultural shock; lack of self-belief; self-effectiveness and failure to manage pressure brought by the complexity of the job; complex and constraining profession; lack of cultural awareness; and, sources of stress and lack of support (Slater et al., 2008; Wildy and Clarke, 2008; and Walker, 2006).In view of these challenges, this therefore is suggestive that school administrators must be equipped with proper skills and competence for them to be able to ride to such challenges rather than be overwhelmed by it.

It is common knowledge that every year school administrators undergo various trainings and seminars in order to update their knowledge as well as enhance their competencies relative to their role as school administrators. Because of this, the Department of Education spent more than Php300 million in training activities (Briones, 2019), and a considerable part of these amount were given for training activities that have something to do in improving school's administrators functioning in the administration of schools. Given the considerable amount of money and resources expended for this purpose, it is, therefore, imperative to come up with a study that would determine whether these training activities given to school's administrators were aligned with their professional development needs. This is in order to ensure responsiveness and cost-effectiveness when it comes to trainings intended for school's administrators. In so doing, this study could provide a concrete response to the call by DepEd (2018) that training activities must not only be responsive, but more so, prudent, economical, and reasonable.

At present, there is an existing dearth of available studies on the extent of alignment of school-heads trainings relative to their professional development needs, be it in DepEd schools in the Philippines or in a particular region or school's division in particular. At present this is glaring in the area of educational management particularly in the Philippine educational context as far as this issue of alignment is concerned. As a consequence, this gap serves as an opening in which researches and studies would be of great assistance, and if addressed, will have practical utility for DepEd regulatory considerations. Thus, through this study it could fill-in such gap though the scope was limited only to the City Schools Division of Cagayan de Oro. However, through this study it could pave the way wherein other schools division in the Philippines would be able to replicate it, thereby, come up with their own assessment of the extent of alignment of the trainings conducted to their school's administrators vis-à-vis their professional development needs. In this way, schools divisions would be able to provide concrete response to the call of the Department of Education to make training activities not only be responsive, but likewise prudent, economical, and reasonable.

\section{Method}

The study utilized a descriptive school heads' questionnaire which include their profile, the trainings they have attended and the relevance of trainings attended to their duties and responsibilities as school managers.

The questionnaire is composed of different parts. The first part is the socio-demographic profile of the schoolheads which include their age bracket, position/designation, educational qualifications and administrative experience. The second part elicited the trainings/seminars attended in which there are 11 identified types of topics. A portion of the questionnaire assessed the following: a.) agreement of school heads on trainings and seminars attended relative to their professional development needs b.) Correlation between school heads training and OPCRF competencies Another set of questions addressed the following a.) Frequency and percentage distribution of school heads' trainings and seminars attended to meet their professional development needs b.) Frequency and percentage distribution of effective ways of delivering trainings/seminars c.) Frequency and percentage distribution of effectiveness of trainings/seminars by length of time and by level of effectiveness d.) By timing of trainings and by level of effectiveness e.) Frequency and percentage distribution of trainings and seminars attended and by level of effectiveness City Schools Division of Cagayan de Oro SY 2019 - 2020.

The questionnaire used was researcher's made, and this was tested for validity and reliability. In testing the former exploratory factor analysis was used, and the latter was determined with the use of Cronbach Alpha alpha in which the questionnaire reliability coefficient was 0.830 for the items on core behavioral competencies and 0.867 for items on leadership competencies.

It must also be emphasized that the meaning of school administrators as understood in this study is similar with that of school-principals.

\subsection{Research Design}

The Exploratory Sequential Mixed Method in combination with Archival Research Method was utilized in the study. It used qualitative then followed by quantitative methods of data gathering and analysis. It sought to analyze the alignment of trainings and seminars attended by elementary school heads to their professional development needs and its 
effect to school performance.

\subsection{Data Collection and Analysis}

The study's research design is Exploratory Sequential Mixed Method, a qualitative data was gathered first by means of FGD.

After the questionnaire have been constructed thereafter subjected to, and passed the test of validity and reliability, it was used to collect numerical data using a 5 point Likert type scale designed to determine the extent of alignment or misalignment of the trainings given to school-heads with that of their development needs.

The structured part of the questionnaire measured alignment or misalignment by way of school-heads personal agreement or disagreement of the responsiveness of the trainings they have attended relative to their professional development needs.

In conjunction with this, archival research was also done to complement and reinforced the data collected by means of the FGD and the structured questionnaire.

\section{Findings and Discussions}

The study utilized total enumeration of all elementary schools school-heads in the City Schools Division of Cagayan de Oro in which there were seventy-two of them. Thus, the findings in this study are reflective of all the schoolheads viewpoints and sentiments with regards to their trainings/seminars attended vis-à-vis the alignment of such trainings/seminars relative to their professional development needs of being school-heads.

At this juncture, it would be more fitting to first present some salient socio-demographic characteristics of schoolheads involved in this study.

Of the seventy-two public elementary school-heads $31.9 \%$ belonged to the age-bracket of 50 years old and above. This was then followed by $25 \%$ in the age-bracket $40-44$ years old, $23.6 \%$ in $45-49$ years old, $16.7 \%$ in $35-39$ years old, and $2.8 \%$ in 30-34 years old. No school-heads, however, belong to the age-bracket 30 years old and below.

In the age-brackets between 30 years old to 50 years old and above, $58.3 \%$ of which were males and $41.7 \%$ females. This connote that the numbers of female schools-administrators are now catching up; and also suggestive of the current level of gender and development that the City Schools Division of Cagayan de Oro have so far attained. This must be noted here since this is a human resource issue that called for equal participation of women and men in all areas of work (UNICEF, 2017). To achieve balance in staffing patterns is could lead improve overall effectiveness of policies and programs of the City Schools Division of Cagayan de Oro, and will therefore could enhance the Division's capacity to better serve the entire population of Cagayan de Oro City (UNICEF, 2017a).

\begin{tabular}{|c|c|c|}
\hline 1.2. Age & $\begin{array}{c}\text { 1.3. } \boldsymbol{F} \\
\text { 1.4. }(N=72)\end{array}$ & 1.5. \% \\
\hline 1.6. 30 years old and below & 1.7. 0 & 1.8. 0.0 \\
\hline 1.9. $30-34$ years old & 1.10 .2 & 1.11 .2 .8 \\
\hline 1.12. $35-39$ years old & 1.13 .12 & 1.14 .16 .7 \\
\hline 1.15. 40-44 years old & 1.16 .18 & 1.17 .25 .0 \\
\hline 1.18. 45-49 years old & 1.19 .17 & 1.20 .23 .6 \\
\hline 1.21. 50 years and Above & 1.22 .23 & 1.23 .31 .9 \\
\hline 1.24. Sex & $\begin{array}{c}\text { 1.25. } \boldsymbol{F} \\
\text { 1.26. }(N=72)\end{array}$ & $1.27 . \%$ \\
\hline 1.28. Male & 1.29 .42 & 1.30 .58 .3 \\
\hline 1.31. Female & 1.32 .30 & 1.33 .41 .7 \\
\hline
\end{tabular}

In terms of school-heads position-designation, $62.5 \%$ have a rank of Principal I and II. This was followed by $16.7 \%$ Head-Teachers, $11.1 \%$ Principal III and IV, and only $9.7 \%$ have position-designation of School In-Charge. At first glance of this finding, one would be lead to suppose that there more positions available for Principals I and II in the Schools Division of Cagayan de Oro compared to the other position-designations. Given the fact that Principals I and II is the dominant position-designations, this implied that the holder of these positions have a master's degree in the field of administration, supervision, leadership or management with a doctoral units (Llego, 2020). This

observation is supported by the empirical data that showed $41.7 \%$ of school-heads have an educational qualification of being a master's degree holder with doctoral units.

It must also be noted that the position-designations of school-heads corresponded to $15.3 \%$ who were master's 
degree holder followed by $13.9 \%$ with doctorate degree while $41.7 \%$ still pursuing their doctorate degree as compared to $29.2 \%$ still working for their master's degree. It is interesting to underscore that no school-heads is holder of a bachelor's degree, which is a positive indication of the professional development thrust in the City Schools Division of Cagayan de Oro as it relate particularly to school-heads.

On the side of administrative experience, school-heads experience in the administration of schools varies. So far, no school-heads have administrative experience below one year. However, there were $36.1 \%$ of schools-heads with administrative experience of over 10 years in contrast to $23.6 \%$ with 1-3 years administrative experience. This was then followed by $22.2 \%$ with 4-6 years administrative experience, and $18.1 \%$ with $7-9$ years administrative experience. These data is connotes that in the coming years to come although those school-heads with 10 years and above experience will ultimately retire the considerable number of school-heads with lesser administrative experience specifically those with $1-3$ years and 4-6 years could serve as potential reserves.

\begin{tabular}{|c|c|c|}
\hline 1.35. Position-Designation & $\begin{array}{c}\text { 1.36. } \boldsymbol{F} \\
\text { 1.37. }(N=72)\end{array}$ & $1.38 . \%$ \\
\hline 1.39. School In-charge & 1.40 .7 & 1.41 .9 .7 \\
\hline 1.42. Head Teacher [I-III] & 1.43 .12 & 1.44 .16 .7 \\
\hline 1.45. Principal [I-II] & 1.46 .45 & 1.47. 62.5 \\
\hline 1.48. Principal [III-IV] & 1.49 .8 & 1.50 .11 .1 \\
\hline 1.51. Educational Qualifications & $\begin{array}{c}\text { 1.52. } F \\
\text { 1.53. }(N=72)\end{array}$ & 1.54. \% \\
\hline 1.55. Doctorate Degree & 1.56 .10 & 1.57. 13.9 \\
\hline 1.58. M.A. Graduate with Doctoral units & 1.59 .30 & 1.60 .41 .7 \\
\hline 1.61. M.A. Graduate & 1.62 .11 & 1.63 .15 .3 \\
\hline 1.64. Bachelor Graduate with Master's units & 1.65 .21 & 1.66. 29.2 \\
\hline 1.67. Bachelor Graduate & 1.68 .0 & 1.69. 0.0 \\
\hline 1.70. Administrative Experience & $\begin{array}{c}\text { 1.71. F } \\
\text { 1.72. }(N=72)\end{array}$ & 1.73. \% \\
\hline 1.74. Below 1 year & 1.75 .0 & 1.76. 0.0 \\
\hline 1.77. $1-3$ years & 1.78 .17 & 1.79. 23.6 \\
\hline 1.80. 4-6 years & 1.81 .16 & 1.82. 22.2 \\
\hline 1.83. 7-9 years & 1.84. 13 & 1.85. 18.1 \\
\hline 1.86. Over 10 years & 1.87. 26 & 1.88. 36.1 \\
\hline
\end{tabular}

Therefore, suggestive that there will be no shortage of school-heads in the coming years to come with enough administrative experience to handle the challenges of the $21^{\text {st }}$ century school environment in the City Schools Division of Cagayan de Oro. However, this is only possible if these administrative experiences of school-heads are match with trainings/seminars responsive to their development needs as school administrators.

\subsection{Trainings/Seminars Attended by School-heads}

To find out whether the training/seminars that were attended by school-heads are in line with their professional development needs as school administrators, they were asked as to the appropriateness of the topics in the trainings/seminars they have so far attended vis-à-vis their professional development needs.

As shown in Table 3 below, there were eleven types of topics in the trainings/seminars that school-heads attended, in which the Schools Division of Cagayan de Oro played significant in the design and conduct of these trainings and seminars. Based on these topics, they were asked as to the appropriateness of said trainings/seminars in the advancement of their professional development needs.

Accordingly, $11.1 \%$ of school-heads respectively agreed that learning outcomes and assessment techniques and differentiated instruction, as the appropriate topics in trainings/seminars for their professional development needs. The topics that garnered the second highest number of consensus at $9.7 \%$ respectively were research, information and media literacy, learning styles and teaching styles, enhanced communication skills, and strategic planning and direction. This was followed by personality development at $8.3 \%$ while passion for results and customer focus, leading change, and navigating 
politics gathered the least consensus at $6.9 \%$, respectively.

\begin{tabular}{|c|c|c|c|}
\hline$\#$ & Topics of Trainings/Seminars School-heads Attended & $\mathbf{F}$ & $\%$ \\
\hline 1 & Learning Outcomes and Assessment Techniques & 8 & 11.1 \\
\hline 2 & Research & 7 & 9.7 \\
\hline 3 & Information and Media Literacy & 7 & 9.7 \\
\hline 4 & Learning styles and teaching styles & 7 & 9.7 \\
\hline 5 & Differentiated instruction & 8 & 11.1 \\
\hline 6 & Enhanced communication skills & 7 & 9.7 \\
\hline 7 & Personality development & 6 & 8.3 \\
\hline 8 & Strategic planning and direction & 7 & 9.7 \\
\hline 9 & Passion for results and customer focus & 5 & 6.9 \\
\hline 10 & Leading change & 5 & 6.9 \\
\hline
\end{tabular}

\begin{tabular}{|c|c|c|c|}
\hline 11 & Navigating politics & 5 & 6.9 \\
\hline \multicolumn{2}{|c|}{ TOTAL } & $\mathbf{7 2}$ & $\mathbf{1 0 0}$ \\
\hline
\end{tabular}

It is surprising to note that no school-heads is able to identify topics on trainings/seminars that primarily focus on leadership as it relates to personal traits of a 21 st century leader, mindsets of a 21 st century leader, skills of a 21 st century leader, habits of a 21 st century leader(Driscoll, 2016). Though these listsmay not be comprehensive nonetheless it captures enduring leadership lessons within the unique, fast-moving circumstances of the early 21 st century(Strock, 2020). Hence, it can be said that there is much that is new and different about leadership, management, and communication in the digital age however there is also significant continuity with earlier times. Therefore, it might be fair enough to declare that the principles endure but the applications change. Consequently, this denote that it is incumbent upon thoseinvolved in the planning of trainings/seminars of school-heads to include these topics though not mentioned by school-heads as part of their development needs.

\subsection{Agreement among School-Heads on trainings/seminars attended relative to Professional Development Needs}

After soliciting the viewpoints of school-heads in relation to the appropriateness of the topic of their trainings/seminars vis-à-vis their professional development needs, the study delve further by attempting to find out whether the aforementioned training/seminars topics were able to address OPCRF prescribed competencies.

Asdisplayed in Table 4, 58.1\% of school-heads strongly agreethat the aforementioned trainings/seminars address theirOPCRF prescribed competencies as compared to $39.8 \%$ whomerely agree. In contrast, .34\% and .23\% disagree and strongly disagree respectively that the abovementioned trainings/seminars address theirOPCRF prescribed competencies while $1.6 \%$ of school-heads reported a response of I do not know.

\begin{tabular}{|l|c|c|c|c|c|}
\hline $\begin{array}{l}\text { Table 4.Frequency and Percentage Distributions of School's Administrators Degree of Agreement Relative to Development } \\
\text { Needs, City Schools Division of Cagayan de Oro City, SY 2019-2020. }\end{array}$ \\
\hline $\begin{array}{l}\text { School-heads agreements } \\
\text { re Development Needs }\end{array}$ & $\begin{array}{c}\text { Strongly } \\
\text { agree }\end{array}$ & Agree & I do not know & \begin{tabular}{c} 
Disagree \\
\cline { 2 - 6 }
\end{tabular} & $\begin{array}{c}\text { Strongly } \\
\text { disagree }\end{array}$ \\
\hline $\begin{array}{l}\text { Trainings/seminars addresses OPCRF prescribed } \\
\text { competencies }\end{array}$ & 58.1 & 39.8 & 1.6 & 0.34 & 0.23 \\
\hline $\begin{array}{l}\text { Appropriateness of OPCRF prescribed } \\
\text { competencies }\end{array}$ & 60.9 & 38.3 & 0.31 & 0.35 & 0.15 \\
\hline
\end{tabular}

In summary, notwithstanding the degree of agreement or disagreement, a total of $92.9 \%$ of school-heads that could be classified as belonging in the agree continuum and only $0.6 \%$ in the disagree continuum.

Moving on, $60.9 \%$ of school-heads strongly agreethat the OPCRF prescribed competencies were appropriate in fulfilling their role and functionswhile $38.3 \%$ merely agree. In contrast, $0.35 \%$ and $0.15 \%$ of school-heads disagree and strongly disagree respectively on the appropriateness of the competencies prescribed in the OPCRF while .31\% of school- 
heads reported a response of I do not know.

Overall, notwithstanding the degree of agreement or disagreement, a total of $99.2 \%$ of school-heads that could be classified as belonging in the agree continuum and only $0.5 \%$ in the disagree continuum.

In view of the fact that the OPCRF prescribed competencies is the standard in which school-heads performance is measured; and since a substantial number of school-heads were in agreement that such trainings/seminars were then considered as able to address their OPCRF prescribed competencies; and not only that, a substantial number of them were also in agreement that the OPCRF prescribed competencies are appropriate in fulfilling their role and responsibilities, hence, suggestive that said training/seminars have provided to the school-heads benefits that made the costs and time of those trainings/seminars a worthwhile investment by the City Schools Division of Cagayan de Oro in particular, and by the Department of Education in general. Therefore, this finding implies one thing that the provision of trainings/seminars toschool-heads, both new and experienced alike, is really cannot be overemphasized(20|20BusinessInsight, 2020).

\subsection{Correlation between School-heads Trainings/Seminars and OPCRF competencies}

At this point, the study would now test if there might be association between school-heads viewpoints that trainings/seminars attended address OPCRF prescribed competencies with their viewpoints that said competencies were appropriate in fulfilling their role and responsibilities.

The rationale behind this is to empirically ascertain how much of the variability of OPCRF prescribed competencies is explainable by trainings/seminars. This is in order to appreciate the extent of trainings/seminars that must be provided to school-heads by the City Schools Division of Cagayan de Oro in particular and the Department of Education in general.

As reflected in Table 5, the correlation coefficient between the viewpoints that trainings/seminars attended address OPCRF prescribed competencies and OPCRF prescribed competencies appropriate for school-heads was $\mathrm{R}=.836, \mathrm{p}<.05$ (2-tailed, t-test), which could be interpreted to mean that the magnitude of the correlation was strong and the direction of the correlation is positive with 0.01 level of significance. Therefore, the said correlation could not be attributed to random chance, indeed, in reality there is an association between the two point-of-views.

\begin{tabular}{|c|c|c|c|}
\hline & & $\begin{array}{l}\text { Trainings/seminars } \\
\text { attended address } \\
\text { OPCRF prescribed } \\
\text { competencies }\end{array}$ & $\begin{array}{c}\text { OPCRF prescribed } \\
\text { competencies appropriate } \\
\text { for school-heads }\end{array}$ \\
\hline \multirow{3}{*}{$\begin{array}{l}\text { Trainings/seminars attended address OPCRF } \\
\text { prescribed competencies }\end{array}$} & \begin{tabular}{|l|} 
Pearson \\
Correlation
\end{tabular} & 1 & $.836^{* *}$ \\
\hline & Sig. (2-tailed) & & .000 \\
\hline & $\mathrm{N}$ & 72 & 72 \\
\hline \multirow{3}{*}{$\begin{array}{l}\text { OPCRF prescribed competencies appropriate for } \\
\text { school-heads }\end{array}$} & \begin{tabular}{|l|} 
Pearson \\
Correlation
\end{tabular} & $.836^{* *}$ & 1 \\
\hline & Sig. (2-tailed) & .000 & \\
\hline & $\mathrm{N}$ & 72 & 72 \\
\hline \multicolumn{4}{|l|}{ Coefficient of Determination $\left(\mathrm{R}^{2}\right)=.6988=69.9 \%$} \\
\hline
\end{tabular}

Since the direction of the correlation is positive, the correlation would imply that for every increase in agreement among school-heads on trainings/seminars that address the OPCRF prescribed competencies, there would also be corresponding increase in their agreement on the appropriateness of OPCRF prescribed competencies. In other words, since these two viewpoints is correlated in the real world not by random chance, it is, therefore, suggestive that, when it comes to the kind of trainings/seminars that school-heads must undergo, their viewpoints should be consulted because such have bearing on the appropriateness of OPCRF prescribed competencies. This therefore implies of a consultative approach with school-heads especially when it comes to determining the topics in trainings/seminars they will undertake. This must be given considerable weight because as revealed in the coefficient of determination $\left(\mathrm{R}^{2}\right), 69.9 \%$ of the variability of agreement on the appropriateness of competencies prescribed in the OPCRF is explainable by school-heads agreement on trainings/seminars that address OPCRF prescribed competencies consequently such variability is large enough to merit serious consideration. However, there is also a need to underscore that there are $30.1 \%$ of variability that trainings/seminars alone could not be explain, therefore, whatever these factors might be it must be identified and given due considerations by planners in the City Schools Division of Cagayan de Oro when they craft their training plans and training modules.

These data shown in Table 6 could provide an insight in relation to the $30.1 \%$ that could not be explained by 
trainings/seminars alone. As reflected, when the school-heads were asked whether the trainings/seminars they attended addressed their professional development needs, $65.3 \%$ replied that it addressed their professional development needs but it failed to provide clearly identified interventions. This failure in trainings/seminars to identify clear interventions might be a factor that must be reckoned with when it comes to that $30 \%$ that is not explainable by trainings/seminars alone.

\begin{tabular}{|l|c|c|}
\hline \multicolumn{2}{|l|}{$\begin{array}{l}\text { Table 6. Frequency and Percentage Distributions of School-heads Trainings/ Seminars Attended that meet their Professional } \\
\text { Development Needs, City Schools Division of Cagayan de Oro City, SY 2019-2020. }\end{array}$} \\
\hline $\begin{array}{l}\text { Were the trainings/seminars attended addressed professional } \\
\text { development needs? }\end{array}$ & $\mathbf{F}$ & $\mathbf{\%}$ \\
\hline Fully addressed with identified interventions & 17 & 23.6 \\
\hline Addressed but interventions not clearly identified & 8 & 11.1 \\
\hline Partially addressed & 0 & 0 \\
\hline Not addressed at all & $\mathbf{7 2}$ & $\mathbf{1 0 0}$ \\
\hline TOTAL & 05.3 \\
\hline
\end{tabular}

\subsection{Factors that Affect Correlation}

\subsubsection{Effective manner of delivering trainings/seminars}

One factor that could affect the magnitude and direction of correlation is the manner of delivering trainings and seminars. Accordingly, Table 7 showed five ways in which trainings/seminars for school-heads is being done in the City Schools Division of Cagayan de Oro.

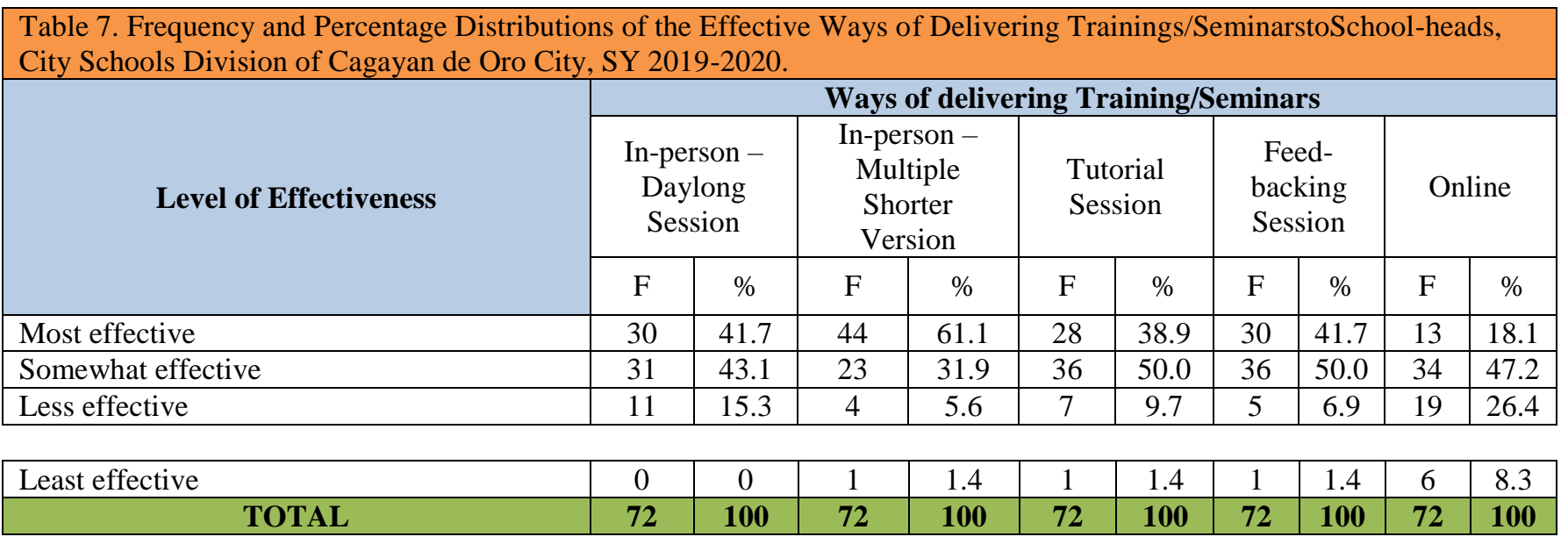

In view of that, the way of delivering trainings/seminars in which $61.1 \%$ of school-heads considered it as most effective was in-person-multiple shorter version. This type of delivery was considered as the most effective because it focuses on face to face type of learning. Most of them stated that in - person is considered more effective since they can readily ask questions from the speaker. They can also easily interact and give their points. Clarifying issues and other gray areas are also good with face to face trainings. They find such type of training more interactive where they could readily raise questions and hear direct answers from the speakers and facilitators. However, they also do not want longer number of days in face to face trainings. They opined that $2-3$ hours would be sufficient in in-person trainings.

The second most effective approach according to school-heads was in-person-daylong session and feed-backing session in which both activities garnered a consensus of $41.7 \%$. This is also a face to face interaction with the speaker in which the participants could raise issues and concerns. They wanted this type of training if the content is highly technical just like introducing a new system. They wanted to be evaluated on their progress. This is usually applied during workshops. The maximum number of days is 1 or 2 days.

Furthermore, the third most effective approach according to school-heads was tutorial session in which $38.9 \%$ of school-heads considered it as such. This approach is similar to a coaching session in which the school head is easily tracked on his/her progress. The school heads who selected this approach find this more effective since feedbacking is more clear. In a large gathering like a seminar, application of learning is not given emphasis but with a tutorial session they also learn fast since it is almost a one on one exchange of learning insights. They find this more productive.

Lastly, online way of delivering trainings/seminars only got an $18.1 \%$ consensus as the most effective activity to 
advance school administrators professional development. Online learning involves online and offline sessions. Most school heads are not agreeable to such type of training. Internet connectivity, low or weak signal, access to different platforms are the common reasons why this type of training is least preferred. Most school heads have only basic information to Information and Communication Technology (ICT). The usual activities they conduct are encoding and preparing reports, web browsing and the use of social media. They are not still open to virtual learning wherein they take courses or attend seminars online. This is yet to be internalized with the school heads who have diverse age bracket since this is one of the latest innovations in learning and development programs.

\subsubsection{Effective length of time of trainings/seminars}

Second factor that could affect the magnitude and direction of the correlation could have something to do with the length of time trainings/seminars were conducted. As to the length of time that schools administrators considered most effective in the delivery of their professional development needs, they were given the following choices: one day, one to two days, three to five days, one week, and more than a week.

As shown in Table 8 below, $65.3 \%$ of school-heads considered that the length of time most effective for trainings/seminars is within the span of three to five days. This was followed by one to two days, and one week as the most effective number of days to conduct trainings and seminars in which both length of time garnered a consensus of $36.1 \%$ and $34.7 \%$, respectively. On one hand, trainings/seminars conducted more than a week got a consensus of $27.8 \%$ while that of one day only gathered a $9.7 \%$ consensus among school-heads.

Although there is no right answer to the question: What is the optimal length of trainings/seminars course (Morgenroth, 2017 ), however, such must not be an activity that school-heads dread. Rather, they should look at these trainings/seminars with eagerness as opportunity for learning more and improving their skills(ExpandShare, 2014). By optimizing trainings/seminars, which is three to four days as the most effective length of time according to school-heads, nevertheless being able to identify beforehand the requirements needed by school-heads with actual application of interventions on the lessons discussed will help the trainings/seminars best fit for school-heads professional development needs, thus, make the trainings/seminars more than white noise.

\begin{tabular}{|c|c|c|c|c|c|c|c|c|c|c|}
\hline \multirow{3}{*}{ Level of Effectiveness } & \multicolumn{10}{|c|}{ Length of time to Conduct Trainings and Seminars } \\
\hline & \multicolumn{2}{|c|}{1 Day } & \multicolumn{2}{|c|}{ 1-2 days } & \multicolumn{2}{|c|}{ 3-5 days } & \multicolumn{2}{|c|}{1 Week } & \multicolumn{2}{|c|}{$\begin{array}{c}\text { More than } \\
\text { a week }\end{array}$} \\
\hline & $\mathrm{F}$ & $\%$ & $\mathrm{~F}$ & $\%$ & $\mathrm{~F}$ & $\%$ & $\mathrm{~F}$ & $\%$ & $\mathrm{~F}$ & $\%$ \\
\hline Most effective & 7 & 9.7 & 26 & 36.1 & 47 & 65.3 & 25 & 34.7 & 20 & 27.8 \\
\hline Somewhat effective & 28 & 38.9 & 27 & 37.5 & 22 & 30.1 & 34 & 47.2 & 27 & 37.5 \\
\hline Less effective & 26 & 36.1 & 18 & 25.0 & 3 & 4.2 & 12 & 16.7 & 22 & 30.6 \\
\hline Least effective & 11 & 15.3 & 1 & 1.4 & 0 & 0 & 1 & 1.4 & 3 & 4.2 \\
\hline TOTAL $(\mathrm{N}=72)$ & 72 & 100 & 72 & 100 & 72 & 100 & 72 & 100 & 72 & 100 \\
\hline
\end{tabular}

\subsubsection{Effective Timing for Trainings/Seminars}

Third factor that could affect the magnitude and direction of the correlation could have something to do with the timing of the conduct of trainings/seminars.

\begin{tabular}{|c|c|c|c|c|c|c|c|c|c|c|}
\hline \multirow{3}{*}{ Level of Effectiveness } & \multicolumn{10}{|c|}{ Timing of Trainings/Seminars } \\
\hline & \multicolumn{2}{|c|}{$\begin{array}{c}\text { Start of Rating } \\
\text { Cycle }\end{array}$} & \multicolumn{2}{|c|}{ Summer } & \multicolumn{2}{|c|}{ Mid-year } & \multicolumn{2}{|c|}{$\begin{array}{c}\text { End of Rating } \\
\text { Cycle }\end{array}$} & \multicolumn{2}{|c|}{$\begin{array}{l}\text { Anytime during } \\
\text { the rating cycle }\end{array}$} \\
\hline & $\mathrm{F}$ & $\%$ & $\mathrm{~F}$ & $\%$ & $\mathrm{~F}$ & $\%$ & $\mathrm{~F}$ & $\%$ & $\mathrm{~F}$ & $\%$ \\
\hline Most effective & 56 & 77.8 & 33 & 45.8 & 27 & 37.5 & 28 & 38.9 & 24 & 33.3 \\
\hline Somewhat effective & 15 & 20.8 & 31 & 43.1 & 35 & 48.6 & 33 & 45.8 & 27 & 37.5 \\
\hline Less effective & 1 & 1.4 & 8 & 11.1 & 10 & 13.9 & 9 & 12.5 & 17 & 23.6 \\
\hline Least effective & 0 & 0 & 0 & 0 & 0 & 0 & 2 & 2.8 & 4 & 5.6 \\
\hline TOTAL $(\mathrm{N}=72)$ & 72 & 100 & 72 & 100 & 72 & 100 & 72 & 100 & 72 & 100 \\
\hline
\end{tabular}


Accordingly, $77.8 \%$ of school-heads considered the start of rating cycle as the most effective timing in conducting trainings/seminars. They emphasized that the start of rating cycle which falls in May is the most appropriate time in attending trainings and seminars. Relative to their identified development needs at the end of the rating cycle, they felt that the competencies identified in their development needs will be addressed. The start of the rating cycle marks a fresh beginning wherein they could acquire knowledge, skills, values and competencies through relevant trainings conducted. They also believe that training designs are based on their development needs. Hence, it should be conducted at the start of the rating cycle.

This was followed by $45.8 \%$ who considered summer as the most effective for doing trainings and seminars. School heads who opted for summer as the best time for trainings also believe that it is between the months of April and May wherein they could improve on their competencies by attending trainings. As clearly stated in Department Order No. 2, s. 2015 "Guidelines on the Establishment of the Results-Based Performance Management System in the Department of Education" the start of the rating cycle for school-based personnel is May. Hence, they wanted to equip themselves during summer break since they have lighter workload compared to the entire school year. They further stressed that they welcome learning opportunities and new insights between the months of April and May.

Moreover, there were $38.9 \%$ who considered end of rating cycle as the most effective timing in the conduct of trainings and seminars as compared with $37.5 \%$ that considered mid-year as the most effective timing. The end of the rating cycle marks

another milestone for school heads. Some believed that it is also good to attend trainings at the end of the rating cycle wherein they already have a good background of their identified development needs. Accordingly, trainings conducted at the start of the cycle will not address the identified gaps since there is a lapse of almost two months. They find trainings conducted at the end of the rating cycle as the best opportunity to acquire new knowledge and skills since Part Four of their Office Performance Commitment and Review Form is the Development Plan. They further asserted that action plans indicated in Part Four should be addressed right away through a training or any learning and development modality.It should not be only stated as a plan but should be put into action and its implementation should be monitored.

While $33.3 \%$ of school-heads considered anytime during the rating cycle as most effective timing for giving trainings and seminars.School heads who responded that anytime during the rating is the most effective timing for giving trainings reasoned that learning can be anytime during the rating cycle. Relatively, they believed that trainings should not have fixed schedules just like at the start or end of the rating cycle. They are versatile and flexible and they have already adjusted to the department's urgent tasks and trainings, multifarious and overlapping schedules of activities and trainings. They also added that it it has become almost a way of life for them especially the constant postponement of scheduled trainings. Hence, they are open to anytime during the rating cycle as effective timing for giving and attending trainings.

\subsubsection{Effective Level of Trainings/Seminars}

Lastly, the fourth factor that could affect the magnitude and direction of the correlation could have something to do with the timing of the conduct of trainings/seminars. On that note, the different levels of trainings/seminars that schoolheads have undertaken were as follows, namely, Division, regional, national, international, and online.

Table 10. Frequency and Percentage Distributions of Trainings and Seminars Attended, and by Level of Effectiveness, City Schools Division of Cagayan de Oro City, SY 2019-2020.

\begin{tabular}{|c|c|c|c|c|c|c|c|c|c|c|}
\hline \multirow{3}{*}{ Level of Effectiveness } & \multicolumn{10}{|c|}{ Level of Trainings/Seminars Attended } \\
\hline & \multicolumn{2}{|c|}{ Division } & \multicolumn{2}{|c|}{ Regional } & \multicolumn{2}{|c|}{ National } & \multicolumn{2}{|c|}{ International } & \multicolumn{2}{|c|}{ Online } \\
\hline & $\mathrm{F}$ & $\%$ & $\mathrm{~F}$ & $\%$ & $\mathrm{~F}$ & $\%$ & $\mathrm{~F}$ & $\%$ & $\mathrm{~F}$ & $\%$ \\
\hline Most effective & 61 & 84.7 & 61 & 85.9 & 53 & 76.8 & 36 & 72.0 & 28 & 40.0 \\
\hline Somewhat effective & 9 & 12.5 & 8 & 11.3 & 12 & 17.4 & 8 & 16 & 17 & 24.3 \\
\hline Less Effective & 2 & 2.8 & 2 & 2.8 & 3 & 4.4 & 6 & 12 & 18 & 25.7 \\
\hline Least effective & 0 & 0 & 0 & 0 & 1 & 1.5 & 0 & 0 & 7 & 10.0 \\
\hline TOTAL & 72 & 100 & 71 & 100 & 69 & 100 & 50 & 100 & 70 & 100 \\
\hline
\end{tabular}

At this point, there is a need to underscore that the number of school-heads that attended trainings/seminars at the division, regional, national, international levels and the online differed. This is because not all seventy-two school-heads attended trainings/seminars at the division level at the same time. Thus, as shown in Table 10 seventy-one have attended trainings/seminars at the regional level, sixty-nine at the national level, fifty at the international level, and seventy at online level.

Therefore, the level of trainings/seminars considered most effective were those that were done at the regional level with $85.9 \%$ of school-heads that attended such trainings/seminars made such observation. They find regional level trainings most effective since training designs are cascaded from the national level. Most of the facilitators and speakers in a regional training were chosen and have attended a National Level Training of Trainors (NTOT). They have trust in the facilitators who are handling the trainings. They have also observed that most facilitators in a regional training are certified National Educators Academy of the Philippines (NEAP) facilitators who have undergone rigid training on facilitation skills. They are 
more comfortable and assured with the quality of training if this is conducted at the regional level.

This was then followed by trainings/seminars conducted at the division levels in which $84.7 \%$ of school-heads considered it as such. There is a slight difference of school heads who are assured on the quality of training conducted at the regional level and division level trainings. Relatively, those were sent to regional trainings which also serve as the Regional Training of Trainors (RTOT) believed that they were carefully chosen to deliver the expected outcomes in division trainings. Hence, they averred that division level trainings are the most effective. They reasoned further that it is in this level wherein they get closer to the actual implementation of the learning insights gained in the training. They further claimed that division level trainings they have attended or facilitated are accurate, specific and clear. The learning objectives, session guides and materials are contextualized to the needs of the participants. They can also relate well with division level trainings and their queries are easily addressed. Accordingly, there is much more learning in division level trainings

This was followed by those trainings and seminars they attended at the national level at $76.8 \%$, international level $72.0 \%$, and online trainings and seminars at $40 \%$. School heads pointed that national level trainings are equally effective. However, participants sent to national level trainings are limited because of the cost involved including travelling expenses. They find national trainings very comprehensive and participants have the privilege of getting first hand information from the experts. They also feel that school heads sent to national trainings were carefully chosen as to competence and skills to cascade the trainings he/she attended.

For international trainings, school heads affirmed that expertise in a particular field of certain qualifications are primary considerations for one to be included in such

trainings. They believed that international trainings is a hallmark of excellence. They also added that international trainings are benchmark of global standards and that it encompasses all levels of trainings. They stressed that it is the highest form of training a school head could have. In the ranking and promotion guidelines, international trainings are given the highest points.

For online trainings and seminars, not all school heads have stable internet connection. Most of them are also not exposed to offline and online resources. However, for those who believed that online trainings and seminars are the most effective, they emphasized that online trainings should be the direction in such a VUCA (volatile, uncertain, complex, ambiguous) world. Conclusively, they pointed that this is the latest trend in learning and should be every school head's direction. This should be the best modality in conducting trainings. It is cost efficient and time saving. The materials used are comprehensive and up to date. They can also interact in 'real time' with the different platforms used. They have already tried online courses and they professed as to its effectiveness and efficiency. They also find it more productive.

\section{Conclusion}

Based on the findings, it is concluded, that trainings and seminars conducted in the City Schools Division of Cagayan de Oro City were aligned with the professional development needs of the school heads as they perform their roles and functions. The OPCRF prescribed competencies are also considered in the trainings intended for school heads. However, not all topics in the trainings and seminars conducted were able to address the desired competencies as indicated in their professional development needs.

It is further concluded that although there is alignment of the trainings and seminars attended by school heads, there is still a need to consult them or summarize their professional development needs in identifying topics for trainings and seminars conducted at different levels.

Acknowledgements

Our heartfelt thanks and appreciation to all those who in one way or another, encouraged and facilitated the completion of this paper:

Cherry Mae L. Limbaco, Ph.D., CESO V, Schools Division Superintendent of the Department of Education, Division of Cagayan de Oro City, for the support and encouragement during the data gathering;

Alicia E. Anghay, Ph.D., Assistant Schools Division Superintendent, for the guidance and insights;

The elementary school heads of the sampled schools of the Department of Education Division of Cagayan de Oro for allowing the researchers to administer the structured questionnaire;

To the Public Schools District Supervisors and school heads who assisted in retrieving the questionnaires;

To our partners for life, Emmanuel and Lita, for their unending encouragement. Our felicitations are beyond compare;

To our children and grandchildren for providing us with joy, affection, warmth and love; and

To the "Omnipotent and Greatest Almighty", for His gift of wisdom, strength and breathe of life. 


\section{References}

20|20BusinessInsight. (2020, March 30). The Importance of Training and Development in the Workplace. Retrieved from 2020projectmanagement.com: https://2020projectmanagement.com/index.cfm?topNav=resources\&subNav=project-management-training-and-qualifications \&subsubNav=theimportance-of-training-and-development-in-the-workplace

Barnett, K., and McCormic, J. (2012). Leadership and Team Dynamics in Senior Executive Leadership Teams, Educational Management Administration and Leadership, 40 (6): 653671.

Briones, Leonor M. (2019). Response to the 2018 COA Audit Report on the Department of Education. Secretary Leonor Magtolis Briones. Department of Education.Retrieved from https://www.deped.gov.ph/wp-content/uploads/2019/08/15663146114107.pdf. Accessed2/3/2020, 10:13 AM.

DepEd.(2010). DepEd Order No. 32 Series of 2010."The National Adoption and Implementation of the National Competency-Based Standards for Schoolheads".Retrieved

http://wbgfiles.worldbank.org/documents/hdn/ed/saber/supportingdoc/EAP/Teachers/Philippines/DO\%20No.\%2032,\%20s.\%202010ncbts $\% 20$ for $\% 20$ School\%20heads.pdf. Accessed 1/30/2020, 12:50 PM.

DepEd. (2018). Office Order No. 2018-093 dated October 2018 entitled "Venue of Activities of the Department of Education Central Office".Retrieved from https://ptvnews.ph/deped- underscores-need-for-training-and-development-programs-for-teachers-personnel/. Accessed 1/30/2020, 10:40 AM.

Driscoll, M. (2016). Think Strategic for Schools. Retrieved from SCHOOL LEADERSHIP FOR THE 21ST CENTURY: https://thinkstrategicforschools.com/leadership-in-schools/

ExpandShare.( 2014, April 28). www.expandshare.com. Retrieved from Finding the Optimal Length for $\quad$ Your Training Course: HYPERLINK "https://www.expandshare.com/blog/finding-the-optimal-length-for-your-" https://www.expandshare.com/blog/finding-the-optimal-length-foryour- training-course.

Fullan, M. (2002).The change leader.Educational Leadership.May, 15-20.

OECD. (2001). Report on Hungary/OECD seminar on Managing Education for Lifelong Learning, 6-7

December 2001, Budapest.

Leithwood, K., Jantzi, D., \& Steinbach, R. (2002).School leadership and the New Right. In K. Leithwood, P. Hallinger, G. Furman, P. Gronn, J. MacBeath, B. Mulford, and K. Riley. (eds). Second international handbook of educational leadership and administration. Norwell, MA: Kluwer. Pp. $\quad 849-880$.

BIBLIOGRAPHY V 13321 Llego, M. A. (2020). Updated DepEd Promotion and Reclassification Guidelines. Retrieved from TEACHERPH.com: https://www.teacherph.com/deped-promotion-reclassification-guidelines/.

BIBLIOGRAPHY 113321 Morgenroth, J. (2017, September 2). 5 Things To Consider To Find The Optimal Length Of A Training Course. Retrieved from elearningindustry: https://elearningindustry.com/length-of-a-training-course-5-things-consider.

Slater, C. L., Garcia, J. M. and Gorosave, G. L. (2008) 'Challenges of a successful first-year principal in Mexico', Educational Administration 46, (6).pp 702-714.Retrieved from HYPERLINK "http://www.emeraldinsight.com/Insight/viewPDF.jsp?contentType=Article\&Filename" http://www.emeraldinsight.com/Insight/viewPDF.jsp?contentType=Article\&Filename . Accessed 2/3/2020, 3:39 PM.

BIBLIOGRAPHY $\backslash 113321$ Strock, J. (2020, January 28). 25 Essential 21st Century Leadership Skills. Retrieved from servetolead.org: https://servetolead.org/25-essential-21st-century-leadership-skills/

Tyack, D., \& Cuban, L. (1995).Tinkering towards utopia: A century of public school reform. Cambridge, MASS.: Harvard University Press.

BIBLIOGRAPHY $\backslash 1$ 13321 UNICEF. (2017). GENDER EQUALITY. Retrieved March 28, 2020, from unicef.org: https://www.unicef.org/rosa/media/1761/file/Gender\%20glossary\%20of\%20terms \%20and\%20concepts\%20.pdf

UNICEF. (2017a). Gender Equality. Retrieved from unicef.org: https://www.unicef.org/gender-equality

Walker, C. (2008) Black Women in Educational Management, in Ozga, J (eds.) Women in Educational Management. Buckingham. Open University Press.

Wildy, H and Clarke, S. (2008) Charting an arid landscape: the preparation of novice primary principals in Western Australia. School Leadership and Management, 28, (5):469-487. 